\title{
Colonization of hardwood and pine wood chips by mites (Acari), with particular reference to oribatid mites (Oribatida)
}

\author{
Andrzej Klimek $\bowtie$, Bogustaw Chachaj \\ University of Science and Technology, Faculty of Animal Breeding and Biology, Mazowiecka 28, 85-084 Bydgoszcz, \\ Poland, e-mail: klimek@utp.edu.pl
}

\section{Abstract}

The study was conducted in the years 2011-2012, in a forest nursery in Białe Błota (Bydgoszcz Forest District). The experiment was established in a $20 \mathrm{~m}$ wide belt of trees within a 110 years old stand growing on mixed fresh coniferous forest site. Litter bags containing hardwood and pine wood chips were placed on mineral soil of microplots and covered with a $5 \mathrm{~cm}$ layer of litter. The pattern of chips colonization differed between mites belonging to different orders. Predatory Mesostigmata colonized hardwood chips gradually but they were present in high numbers in pine chips from the beginning of the study. Abundance of Actinedida fluctuated within the two-year study cycle. Contrary to that, oribatid mites, which were a predominant mite type, colonized both types of chips gradually, while preferring the pine ones. At the end of the study, the structure of mite communities and mite abundance in pine chips were more similar to forest soil than in hardwood chips. The experiment demonstrated that pine chips provided most oribatid mites with more favorable living conditions than hardwood chips, as they were colonized at a quicker rate and by a greater number of species. The most abundant oribatid mite in both substrates was a eurytopic Tectocepheus velatus that showed no clear preferences towards either of the substrates. Majority of oribatid mites, e.g. Oppiella nova, Metabelba pulverulenta, Oribatula tibialis, Chamobates schuetzi, Galumna lanceata, preferred pine chips. The only species with clear preference for hardwood chips was Eniochthonius minutissimus. A comparison of usefulness of hardwood and pine wood chips in revitalization of degraded soils based on bioindication approach indicated higher suitability of pine chips that are also more available in Polish forests.

\section{KeY WORDS}

litter bags, species diversity, oribatid mites, bioindication, soil revitalization

\section{INTRODUCTION}

Wood chips have been for years successfully used for mulching orchard crops (Treder et al. 2004, 2009). Their effectiveness is mostly due to their positive effects on soil moisture, temperature distribution or inhibition of weed growth. The chips were also reported to positively affect the presence of soil mesofauna (Klimek et al. 2014a, 2014b). They may be therefore used for revitalization of degraded soils, particularly those deprived of organic matter layer.

The foresters managing State Forests did not use to pay much attention to logging residues - they were usually piled and burnt on the site (Sadowski et al. 2012). Currently, the logging residues are usually disintegrat- 
ed with shredders that provide biomass in the form of wood chips. Chips may be then scattered on the cutting site or used e.g. for energy production. Although most of biogenic elements are accumulated in the soil, it is recommended that some of the biomass from the finest tree parts is left on the cutting site area intended for regeneration (Sadowski et al. 2012).

Plants are relatively easy to restore on degraded areas but the greatest challenge is to restore natural structure of typical forest soil mesofauna. Possible causes of this situation include a lack of litter layer typical for forest soils and limited possibilities of spreading and colonizing new sites by soil microarthropods (Beckmann 1988; Lehmitz et al. 2011; Wanner and Dunger 2002). Therefore, some chips obtained during logging in forests may be used to accelerate forest succession during revitalization of degraded areas.

However, research literature lacks reports on the rate of chips colonization by soil fauna. It is also unclear what type of wood chips is more suitable for forest soil regeneration, i.e. those obtained from broad leaved trees or from Scots pine that dominates in Polish forests.

The aim of this study was to compare the rate of colonization of pine and hardwood chips by mites (Acari), with special attention to oribatid mites (Oribatida). The study was conducted in a two-year cycle using litter bags covered with forest soil litter.

\section{MATERIAL AND METHODS}

The study was conducted in the years 2011-2012, in a forest nursery in Białe Błota (Bydgoszcz Forest District). The experiment was established in a $20 \mathrm{~m}$ wide belt of trees $\left(53^{\circ} 06^{\prime} 13.2^{\prime \prime} \mathrm{N}, 17^{\circ} 55^{\prime} 46.6^{\prime \prime} \mathrm{E}\right)$ in order to mitigate the influence of weather conditions, such as excessive sunlight, temperature fluctuations or too intensive precipitation. The tree stand included Scots pine (Pinus sylvestris L.), oak (Quercus sp. L.) and European ash (Fraxinus excelsior L.), and the underbush layer was composed by Norway maple (Acer platanoides L.), European ash, silver birch (Betula pendula Roth), and oak. The stand was around 110 years old and it was growing on the fresh mixed coniferous forest site. The soil type was albic brunic arenosol (Bydgoszcz Forest Inspectorate data).
Litter bags of the size $15 \times 20 \mathrm{~cm}$ were made of nylon mosquito net with $2 \mathrm{~mm}$ mesh. This allowed for free migration of soil mesofauna species. The chips were obtained with a circular chopper from the branches of roadside broad leaved trees (Tilia cordata Mill. and Acer platanoides L.) and separately from pine branches from a pine forest. Immediately prior to placing the chips in the litter bags, they were additionally shredded two times with a garden shredder VIKING GE 250. The bags containing $1.5 \mathrm{dm}^{3}$ of chips each were placed on respective microplots.

The microplots with the area of $1 \mathrm{~m}^{2}$ each were arranged in two rows (Fig. 1). The distance between individual microplots was about $1 \mathrm{~m}$. The experiment included two variants, i.e. litter bags with hardwood chips ( $\mathrm{Hc}$ ) and pine wood chips $(\mathrm{Pc})$. Additionally, organic horizon between the microplots (L) was analyzed. Each experimental variant included four microplots. Six bags were pleased on each microplot with the aim of collecting six samples. The bags were placed on mineral soil and covered with a $5 \mathrm{~cm}$ layer of litter.

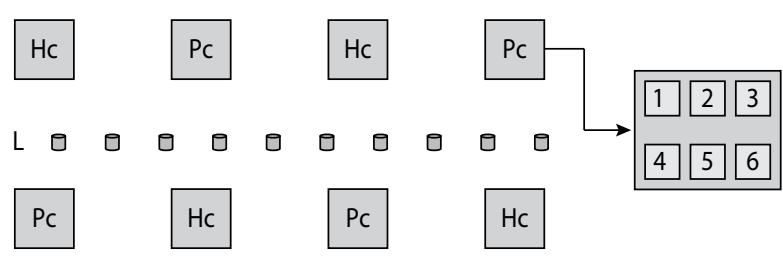

Figure 1. Location of microplots and sampling sites at the bottom of a forest stand Białe Błota forest nursery. Explanations: $\mathrm{Hc}$ - litter bags with hardwood chips, $\mathrm{Pc}$ - litter bags with pine wood chips, $\mathrm{L}$ - place of sampling from the organic horizon, $1 \ldots 6-$ litter bags with chips (next research dates)

To maintain optimum moisture content, the microplots were irrigated by micro sprinklers as per the guidelines and schedule for irrigation of nurseries, and mean soil moisture was kept at 5.1-9.9\%.

The samples for acarological analyses were collected in the spring, summer and autumn of each study year on the following days: $24^{\text {th }}$ May 2011, $20^{\text {th }}$ July $2011,27^{\text {th }}$ October 2011, $19^{\text {th }}$ May 2012, $10^{\text {th }}$ July 2012 , and $16^{\text {th }}$ October 2012. Each time, 10 samples were taken from each variant: four litter bags from four different microplots $(2+3+2+3)$ and from the organic 
horizon dividing the microplots. A total of 60 samples of $50 \mathrm{~cm}^{3}$ each were collected during the study from every variant $(\mathrm{Hc}+\mathrm{Pc}+\mathrm{L})$. Mite extraction was carried out over seven days using Tullgren funnels. Then, the mites were preserved in $70 \%$ ethanol. All the mites were classified into orders and oribatid mites into species or genera, with regard to juvenile stages. A total of 9318 mites were determined, including 5765 oribatid mites.

Average density $(N)$ of the mites was provided for $50 \mathrm{~cm}^{3}$ of the substrate, and species dominance index $(D)$ was given in percentage. Species diversity of oribatid mites was determined based on the number of species $(S)$, mean number of species per sample $(s)$ and Shannon's diversity index $\left(H^{\prime}\right)$. Prior to statistical analysis, numerical data were subjected to a logarithmic transformation $-\ln (\mathrm{x}+1)$ (Berthet and Gerard 1965). The statistical analysis was performed using Statistica 12.0 software: compliance of measurable parameters with normal distribution was assessed using Kolmogorov-Smirnov test. As the normal distribution was not confirmed, a non-parametric analysis of variance (Kruskal-Wallis $H$ test) was performed. For statistically significant differences $(p<0.05)$ a analysis for each pair was carried out (Mann-Whitney $U$ test) to identify significantly different means. The cluster analysis of the variants of experiments was carried out using the Ward's method based on Euclidean distance (Statistica 12.0 software).

Samples for chemical analysis of the investigated substrates were collected on the first and last sampling date (24 $4^{\text {th }}$ May 2011 and $16^{\text {th }}$ October 2012). The analyses were carried out at the Laboratory of Chemical Pol- lution of the Institute of Horticulture in Skierniewice. $\mathrm{pH}$ was determined by electrochemical method and $\mathrm{N}_{\text {total }}$ content and $\mathrm{C}_{\text {org }}$ content were figured out according to Dumas using TruSpec CNS analyzer.

\section{Results}

\section{Meteorological conditions and chemical analysis of substrates}

Mean air temperature in the growing period of 2011 was by $0.7^{\circ} \mathrm{C}$ higher than the mean for a multi-year period (Tab. 1), with particularly high temperatures in April and in autumn. Mean air temperature in 2012 was similar to that of the multi-year period. In both years, total annual precipitation was higher than average for the multi-year period. Worth noticing was extremely low monthly precipitation in April, May and October of 2011, as compared with a normal range. In 2012, total annual precipitation in the growing period was by $41.4 \mathrm{~mm}$ higher than the normal range and by $15.4 \mathrm{~mm}$ higher than in 2011.

Hardwood chips featured relatively stable $\mathrm{pH}$ of 6.8-6.9 at the beginning and end of the study (Tab. 2). Contrary to that, low $\mathrm{pH}$ of 5.7 observed in pine chips in May 2011 increased up to 6.4 in October 2012. At the beginning of the study, the content of total nitrogen was the same in both types of chips and equaled $1.3 \%$ a.d.w. Its level was constant throughout the study in hardwood chips but dropped down to $0.5 \%$ a.d.w. in pine chips. The content of total carbon was in both substrates much higher at the beginning than at the end of the study. Exceptionally high carbon content

Table 1. Air temperature and precipitation in 2011-2012 (data for the Research Center Mochełek near Bydgoszcz, processed by the Department of Melioration and Agrometeorology of University of Science and Technology in Bydgoszcz)

\begin{tabular}{|c|c|c|c|c|c|c|c|c|c|}
\hline \multirow[b]{2}{*}{ Parameter } & \multirow[b]{2}{*}{ Year } & \multicolumn{8}{|c|}{ Months } \\
\hline & & April & May & June & July & August & September & October & $\begin{array}{c}\text { April- } \\
\text { October }\end{array}$ \\
\hline \multirow{3}{*}{$\begin{array}{l}\text { Air temperature } \\
\left({ }^{\circ} \mathrm{C}\right)\end{array}$} & 2011 & 10.5 & 13.5 & 17.7 & 17.5 & 17.7 & 14.3 & 8.4 & 14.2 \\
\hline & 2012 & 8.4 & 14.5 & 15.2 & 18.8 & 17.6 & 13.3 & 7.4 & 13.6 \\
\hline & Long-term value & 8.0 & 13.0 & 16.3 & 18.5 & 17.8 & 13.1 & 7.8 & 13.5 \\
\hline \multirow{3}{*}{$\begin{array}{l}\text { Precipitation } \\
(\mathrm{mm})\end{array}$} & 2011 & 13.5 & 38.4 & 100.8 & 132.5 & 67.7 & 37.0 & 13.2 & 403.1 \\
\hline & 2012 & 26.5 & 25.4 & 133.8 & 115.6 & 51.8 & 25.1 & 40.3 & 418.5 \\
\hline & Long-term value & 29.0 & 61.2 & 48.8 & 87.7 & 68.6 & 45.6 & 36.2 & 377.1 \\
\hline
\end{tabular}


of $50.6 \%$ a.d.w. was determined in pine chips in May 2011. Throughout the study, it was reduced to $12.3 \%$ a.d.w. and was two times lower than in hardwood chips. Initial content of organic matter was high in both substrates and amounted to $59.9-87.0 \%$. Then is gradually decreased due to mineralization in both variants, and the decrease was more pronounced in pine chips.

Table 2. Physical and chemical parameters in the experimental variants

\begin{tabular}{|l|c|c|c|c|}
\hline \multirow{2}{*}{ Parameters } & \multirow{2}{*}{ Year } & \multicolumn{3}{|c|}{ Variant of the experiment } \\
\cline { 3 - 5 } & & $\begin{array}{c}\text { hardwood } \\
\text { chips (Hc) }\end{array}$ & $\begin{array}{c}\text { pine wood } \\
\text { chips (Pc) }\end{array}$ & $\begin{array}{c}\text { litter } \\
(\mathrm{L})\end{array}$ \\
\hline \multirow{2}{*}{$\mathrm{pH} \mathrm{H_{2 } \mathrm { O }}$} & 05.2011 & 6.8 & 5.7 & - \\
\cline { 2 - 5 } & 10.2012 & 6.9 & 6.4 & 6.7 \\
\hline \multirow{2}{*}{$\mathrm{N}$ (\% a.d.w.) } & 05.2011 & 1.3 & 1.3 & - \\
\cline { 2 - 5 } & 10.2012 & 1.3 & 0.5 & 0.6 \\
\hline \multirow{2}{*}{$\mathrm{C}(\%$ a.d.w.) } & 05.2011 & 34.8 & 50.6 & - \\
\cline { 2 - 5 } & 10.2012 & 24.2 & 12.3 & 7.3 \\
\hline \multirow{2}{*}{$\begin{array}{l}\text { Organic } \\
\text { matter (\%) }\end{array}$} & 05.2011 & 59.9 & 87.0 & - \\
\cline { 2 - 5 } & 10.2012 & 41.7 & 21.1 & 11.8 \\
\hline
\end{tabular}

Table 3. Abundance of mites ( $N$ in individuals $50 \mathrm{~cm}^{-3}$ of substrate) in the experimental variants

\begin{tabular}{|c|c|c|c|c|c|c|}
\hline \multirow[b]{2}{*}{ Taxon } & \multirow[b]{2}{*}{ Year } & \multicolumn{3}{|c|}{$\begin{array}{l}\text { Variant of the } \\
\text { experiment }\end{array}$} & \multicolumn{2}{|c|}{$\begin{array}{c}\text { Kruskal-Wallis } \\
\text { test }\end{array}$} \\
\hline & & 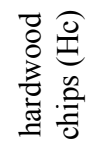 & 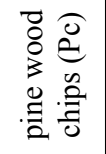 & $\begin{array}{l}\text { litter } \\
(\mathrm{L})\end{array}$ & $\mathrm{H}$ & $\mathrm{p}$ \\
\hline \multirow{2}{*}{$\begin{array}{l}\text { Acari- } \\
\text { dida }\end{array}$} & 2011 & 0 & $0.6^{\mathrm{A}}$ & $1.3^{\mathrm{A}}$ & \multirow{2}{*}{17.94} & \multirow{2}{*}{0.003} \\
\hline & 2012 & 0 & $0.5^{\mathrm{A}}$ & $0.1^{\mathrm{A}}$ & & \\
\hline \multirow{2}{*}{$\begin{array}{l}\text { Actine- } \\
\text { dida }\end{array}$} & 2011 & $5.7^{\mathrm{A}}$ & $3.9^{\mathrm{B}}$ & $5.4^{\mathrm{A}}$ & \multirow{2}{*}{42.56} & \multirow{2}{*}{0.000} \\
\hline & 2012 & $22.0^{\mathrm{A} *}$ & $10.7^{\mathrm{A} *}$ & $17.0^{\mathrm{A} *}$ & & \\
\hline \multirow{2}{*}{$\begin{array}{l}\text { Meso- } \\
\text { stigmata }\end{array}$} & 2011 & $3.4^{\mathrm{A}}$ & $11.0^{\mathrm{B}}$ & $3.6^{\mathrm{A}}$ & \multirow{2}{*}{30.75} & \multirow{2}{*}{0.000} \\
\hline & 2012 & $11.0^{\mathrm{A} *}$ & $10.5^{\mathrm{A}}$ & $5.2^{\mathrm{A}}$ & & \\
\hline \multirow{2}{*}{$\begin{array}{l}\text { Oriba- } \\
\text { tida }\end{array}$} & 2011 & $8.2^{\mathrm{A}}$ & $9.6^{\mathrm{B}}$ & $25.5^{\mathrm{C}}$ & \multirow{2}{*}{77.80} & \multirow{2}{*}{0.000} \\
\hline & 2012 & $34.3^{\mathrm{A} *}$ & $54.8^{\mathrm{B} *}$ & $62.9^{\mathrm{B} *}$ & & \\
\hline \multirow{2}{*}{$\begin{array}{l}\text { Tarso- } \\
\text { nemida }\end{array}$} & 2011 & $0.3^{\mathrm{A}}$ & $2.9^{\mathrm{B}}$ & $0.7^{\mathrm{C}}$ & \multirow{2}{*}{30.06} & \multirow{2}{*}{0.000} \\
\hline & 2012 & $0.3^{\mathrm{A}}$ & $2.0^{\mathrm{B}}$ & $0.3^{\mathrm{A}}$ & & \\
\hline \multirow{2}{*}{$\begin{array}{l}\text { Acari } \\
\text { (Total) }\end{array}$} & 2011 & $17.6^{\mathrm{A}}$ & $28.1^{\mathrm{B}}$ & $36.5^{\mathrm{B}}$ & \multirow{2}{*}{61.41} & \multirow{2}{*}{0.000} \\
\hline & 2012 & $67.7^{\mathrm{A} *}$ & $78.4^{\mathrm{A} *}$ & $85.5^{\mathrm{A} *}$ & & \\
\hline
\end{tabular}

Explanations: ${ }^{\mathrm{A}, \mathrm{B}, \mathrm{C}}$ - the same letter denotes insignificant difference - Mann-Whitney $U$ test at $p<0.05$. $^{*}$ - significant difference between 2011 and $2012-$ Mann-Whitney $U$ test at $p<0.05$.

\section{Abundance of mite communities}

In the first year of the study total number of mites in pine chips was significantly higher than in hardwood chips (Tab. 3). As compared with forest litter, pine chips harbored $77 \%$ of these microarthropods and hardwood chips only $48 \%$. In the second year, the number of mites grew significantly and was more similar. It equaled $79 \%$ and $92 \%$ of the forest litter abundance in $\mathrm{Hc}$ and $\mathrm{Pc}$ variants, respectively.

Table 4. Oribatida/Actinedida abundance ratio, number of Oribatida $(S)$ species, average number of species $(s)$, and $\%$ of juvenile Oribatida forms in the experimental variants

\begin{tabular}{|c|c|c|c|c|c|c|}
\hline \multirow[b]{2}{*}{ Index } & \multirow[b]{2}{*}{ Year } & \multicolumn{3}{|c|}{$\begin{array}{l}\text { Variant of the } \\
\text { experiment }\end{array}$} & \multicolumn{2}{|c|}{$\begin{array}{l}\text { Kruskal- } \\
\text { Wallis test }\end{array}$} \\
\hline & & 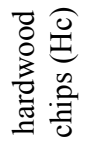 & 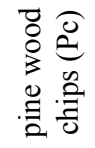 & $\begin{array}{l}\text { litter } \\
(\mathrm{L})\end{array}$ & $\mathrm{H}$ & $\mathrm{p}$ \\
\hline \multirow{2}{*}{$\begin{array}{l}N \text { Oribatida } \\
\text { /Actinedida }\end{array}$} & 2011 & 1.44 & 2.49 & 4.8 & \multirow{2}{*}{ - } & \multirow{2}{*}{ - } \\
\hline & 2012 & 1.56 & 5.12 & 3.7 & & \\
\hline \multirow{2}{*}{$\begin{array}{l}S \text { of Oriba- } \\
\text { tida }\end{array}$} & 2011 & 19 & 21 & 29 & \multirow{2}{*}{ - } & \multirow{2}{*}{ - } \\
\hline & 2012 & 27 & 24 & 27 & & \\
\hline \multirow{2}{*}{$\begin{array}{l}s \text { of Oriba- } \\
\text { tida }\end{array}$} & 2011 & $2.23^{\mathrm{A}}$ & $3.63^{\mathrm{A}}$ & $7.10^{\mathrm{B}}$ & 67.51 & 0.000 \\
\hline & 2012 & $5.47^{\mathrm{A}}$ & $8.20^{\mathrm{B} *}$ & $8.03^{\mathrm{B} *}$ & & \\
\hline \multirow{2}{*}{$\begin{array}{l}H^{\prime} \text { of Ori- } \\
\text { batida }\end{array}$} & 2011 & 2.00 & 2.29 & 2.37 & - & - \\
\hline & 2012 & 1.56 & 2.15 & 1.99 & & \\
\hline \multirow{2}{*}{$\begin{array}{l}\% \text { juv Ori- } \\
\text { batida }\end{array}$} & 2011 & 15.9 & 20.8 & 50.7 & & \\
\hline & 2012 & 55.4 & 45.9 & 54.3 & & \\
\hline
\end{tabular}

Explanations: see table 3.

The most abundant mites in the investigated material were oribatid mites present at 8.2-62.9 individuals $50 \mathrm{~cm}^{-3}$. They accounted for $34-74 \%$ of all mites. In all variants the number of oribatid mites was significantly lower in the first year of the study. In 2011, the differences between variants were significant. The abundance of oribatid mites equaled $32 \%$ of that found in the forest litter in hardwood chips and $38 \%$ in pine chips. In 2012 , these numbers rose up to $55 \%$ and $87 \%$, respectively. The oribatid mites that colonized the investigated substrates clearly preferred pine chips. An analysis of the colonization by seasons (Fig. 2) revealed fluctuations in mite numbers in both substrates in the first year and gradual increase in abundance from spring till autumn 

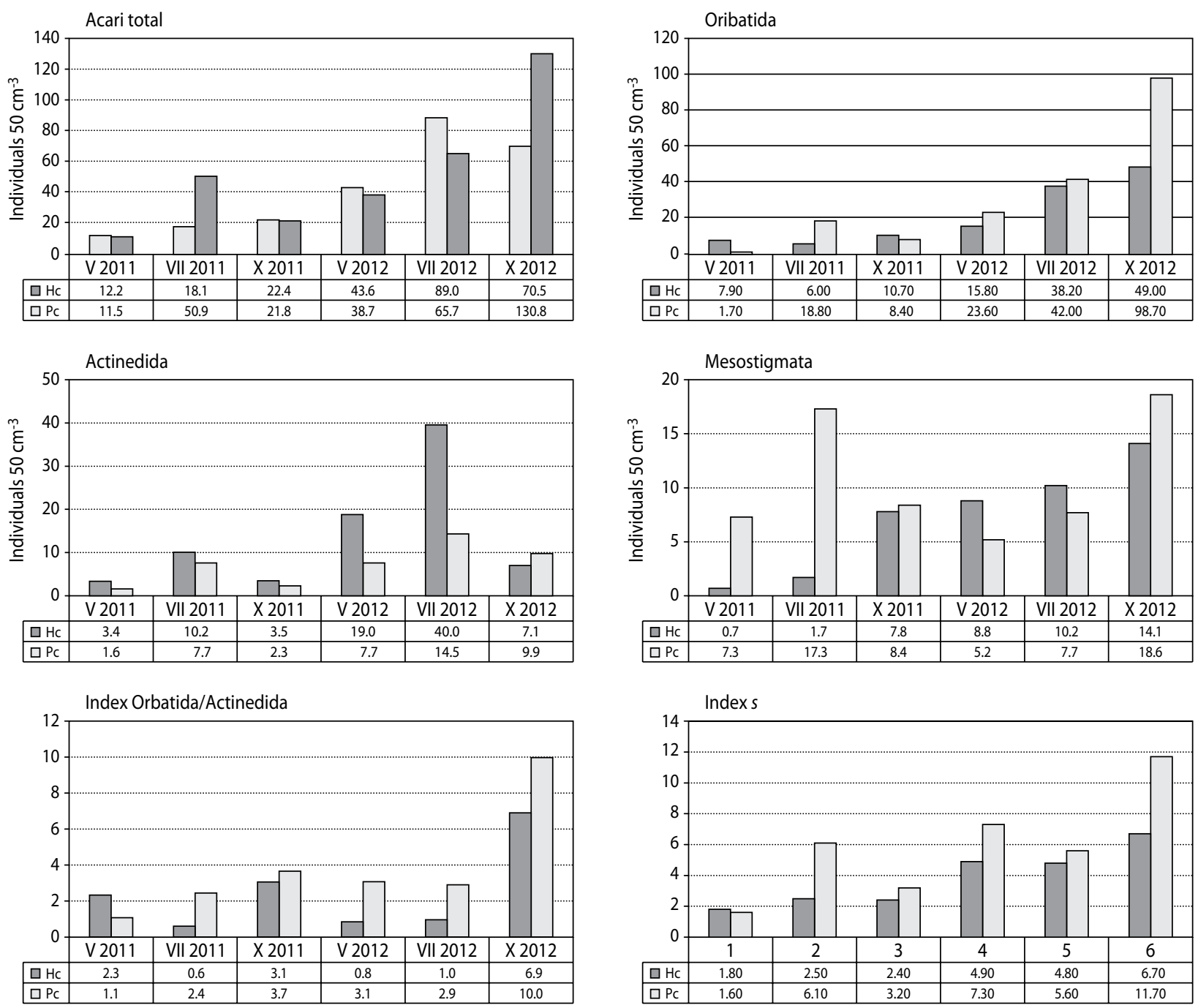

Figure 2. The dynamics of abundance of the mite groups, Orbatida/Actinedia ratio and $s$ index of Oribatida in the investigated experimental variants

in the second year. The greatest boost in abundance in 2012 (from 42 to 98.7 individuals $50 \mathrm{~cm}^{-3}$ ) was observed in pine chips between July and October. The share of juvenile forms of Oribatida in the forest litter in the years 2011-2012 ranged from 50.7 to $54.3 \%$ (Tab. 4). Contrary to that, the chips were dominated by adult forms in the first year and the share of juvenile forms increased in the second year.

Actinedida were the second group of mites identified in the study but they were less abundant (5.7-22.0 individuals $50 \mathrm{~cm}^{-3}$ ) (Tab. 3). Their numbers in the first year was low both in the litter and in the chips but it rose markedly in the second year. They were the most abun- dant in Hc variant. The highest number of Actinedida in the chips was determined for summer 2012. Oribatida to Actinedida ratio that reflects stability of the soil environment was high in the forest litter (3.7-4.8) (Tab. 4). Its lowest mean annual value of $1.44-1.56$ was found in hardwood chips. In the beginning of the study, in May 2011, the ratio was higher in hardwood than in pine chips (Fig. 2). On consecutive sampling dates it was always higher in pine chips, and its maximum values in both types of chips (6.9 for Hc and 10 for Pc) were observed in the autumn of 2012.

Mites belonging to Mesostigmata order accounted for 6 to 39\% of all mites. In the first year, these mites 
Table 5. Abundance of some oribatid species ( $N$ in individuals $50 \mathrm{~cm}^{-3}$ of substrate) in the investigated experimental variants

\begin{tabular}{|c|c|c|c|c|c|c|}
\hline \multirow[b]{2}{*}{ Species } & \multirow[b]{2}{*}{ Year } & \multicolumn{3}{|c|}{ Variant of the experiment } & \multicolumn{2}{|c|}{ Kruskal-Wallis tes } \\
\hline & & $\begin{array}{l}\text { hardwood } \\
\text { chips }(\mathrm{Hc})\end{array}$ & $\begin{array}{l}\text { pine wood } \\
\text { chips }(\mathrm{Pc})\end{array}$ & litter $(\mathrm{L})$ & $\mathrm{H}$ & $\mathrm{p}$ \\
\hline \multirow{2}{*}{ Brachychthonius sp. } & 2011 & $0.8^{\mathrm{A}}$ & $0.4^{\mathrm{A}}$ & $1.1^{\mathrm{A}}$ & \multirow{2}{*}{13.62} & \multirow{2}{*}{0.018} \\
\hline & 2012 & $0.5^{\mathrm{A}}$ & $1.3^{\mathrm{A}}$ & $1.1^{\mathrm{A}}$ & & \\
\hline \multirow{2}{*}{ Chamobates schuetzi (Oudemans) } & 2011 & 0 & $0.1^{\mathrm{A}}$ & $1.2^{\mathrm{B}}$ & \multirow{2}{*}{70.58} & \multirow{2}{*}{0.000} \\
\hline & 2012 & $0.3^{\mathrm{A}}$ & $1.1^{\mathrm{B} *}$ & $4.7^{\mathrm{C} *}$ & & \\
\hline \multirow{2}{*}{ Eniochthonius minutissimus (Berlese 1903) } & 2011 & 0 & 0 & 0.4 & \multirow{2}{*}{36.31} & \multirow{2}{*}{0.000} \\
\hline & 2012 & $2.0^{\mathrm{A}}$ & $0.03^{\mathrm{B}}$ & 0 & & \\
\hline \multirow{2}{*}{ Galumna lanceata (Oudemans) } & 2011 & 0 & $0.2^{\mathrm{A}}$ & $0.3^{\mathrm{A}}$ & \multirow{2}{*}{25.47} & \multirow{2}{*}{0.000} \\
\hline & 2012 & $0.3^{\mathrm{A}}$ & $1.5^{\mathrm{B} *}$ & $1.1^{\mathrm{B} *}$ & & \\
\hline \multirow{2}{*}{ Gymnodamaeus bicostatus (C.L. Koch) } & 2011 & $0.2^{\mathrm{A}}$ & $1.2^{\mathrm{B}}$ & $7.1^{\mathrm{C}}$ & \multirow{2}{*}{105.92} & \multirow{2}{*}{0.000} \\
\hline & 2012 & $0.7^{\mathrm{A}}$ & $7.1^{\mathrm{B} *}$ & $14.1^{\mathrm{C} *}$ & & \\
\hline \multirow{2}{*}{ Metabelba pulverulenta (C.L. Koch) } & 2011 & $0.1^{\mathrm{A}}$ & $1.8^{\mathrm{B}}$ & $1.9^{\mathrm{B}}$ & \multirow{2}{*}{59.31} & \multirow{2}{*}{0.000} \\
\hline & 2012 & $0.3^{\mathrm{A}}$ & $10.1^{\mathrm{B} *}$ & $2.8^{\mathrm{B}}$ & & \\
\hline \multirow{2}{*}{ Oppiella nova (Oudemans) } & 2011 & $0.9^{\mathrm{A}}$ & $0.3^{\mathrm{A}}$ & $0.1^{\mathrm{A}}$ & \multirow{2}{*}{61.14} & \multirow{2}{*}{0.000} \\
\hline & 2012 & $1.6^{\mathrm{A}}$ & $5.6^{\mathrm{B} *}$ & $0.3^{\mathrm{C}}$ & & \\
\hline \multirow{2}{*}{ Oribatula tibialis (Nicolet) } & 2011 & 0 & $0.1^{\mathrm{A}}$ & $3.4^{\mathrm{B}}$ & \multirow{2}{*}{106.56} & \multirow{2}{*}{0.000} \\
\hline & 2012 & $0.9^{\mathrm{A}}$ & $3.1^{\mathrm{B} *}$ & $12.3^{\mathrm{C} *}$ & & \\
\hline \multirow{2}{*}{ Suctobelba sp. } & 2011 & $1.4^{\mathrm{A}}$ & $2.9^{\mathrm{A}}$ & $1.4^{\mathrm{A}}$ & \multirow{2}{*}{31.20} & \multirow{2}{*}{0.000} \\
\hline & 2012 & $4.3^{\mathrm{A} *}$ & $5.3^{\mathrm{A} *}$ & $1.2^{\mathrm{B}}$ & & \\
\hline \multirow{2}{*}{ Tectocepheus velatus (Michael) } & 2011 & $1.9^{\mathrm{A}}$ & $0.7^{\mathrm{A}}$ & $4.7^{\mathrm{A}}$ & \multirow{2}{*}{42.20} & \multirow{2}{*}{0.000} \\
\hline & 2012 & $21.2^{\mathrm{A} *}$ & $16.6^{\mathrm{A} *}$ & $20.4^{\mathrm{A} *}$ & & \\
\hline ribotid mi & 2011 & 2.8 & 2.0 & 3.9 & & \\
\hline C & 2012 & 2.1 & 3.1 & 4.9 & & \\
\hline
\end{tabular}

${ }^{* *} N<1.0$ individuals $50 \mathrm{~cm}^{-3}$ : Achipteria coleoptrata (L) - $2012(\mathrm{H}) ;$ Adoristes ovatus (C.L. Koch) - 2011 (Hc,Pc,L), 2012 (Hc,Pc,L); Autogneta longilamellata (Michael) - 2011 (Pc,L); Camisia spinifer (C.L. Koch) - 2011 (L); Carabodes femoralis (Nicolet) - 2012 (L); C. forsslundi Sellnick - 2011 (L), 2012 (Hc,L); C. labyrinthicus (Michael) - 2011 (L), 2012 (Hc,L); Cepheus cepheiformis (Nicolet) - 2012 (L); Chamobates cuspidatus (Michael) - 2011 (L), 2012 (H); Cultroribula bicultrata (Berlese) - 2011 (Hc); Dometorina plantivaga (Berlese) - 2012 (L); Damaeus sp. 2011 (Pc,L), 2012 (Pc,L); Eremaeus oblongus C.L. Koch 2011 (L), 2012 (Pc); Eupelops torulosus (C.L. Koch) - 2011 (Pc,L), 2012 (L); Heminothrus peltifer (C.L. Koch) - 2011 (L), 2012 (L); Licneremaeus licnophorus (Michael) - 2012 (Pc); Liochthonius sp. - 2011 (Hc,L), 2012 (Hc,Pc,L); Micreremus brevipes (Michael) - 2011 (Hc,Pc,L), 2012 (P); Microtritia minima (Berlese) - 2011 (Pc), 2012 (Hc,Pc); Microzetorchestes emeryi (Coggi) - 2012 (Hc,Pc,L); Nothrus palustris C.L. Koch - 2011 (L), 2012 (Pc); N. silvestris Nicolet - 2011 (Pc); Oribatula 1 - 2011 (Pc,L); Phthiracarus longulus (C.L. Koch) - 2011 (Hc,Pc,L), 2012 (Hc,Pc,L); Quadroppia quadricarinata (Michael) - 2011 (L), 2012 (Hc,Pc,L); Ramusella mihelcici (Pérez-Íñigo) - 2011 (Hc,Pc), 2012 (P); Rhysotritia duplicata (Grandjean) - 2011 (Hc,Pc), 2012 (Hc); Steganacarus carinatus (C.L. Koch) - 2011 (Pc,L), 2012 (Hc,Pc,L); S. striculus - 2012 (Hc); Xenillus tegeocranus (Hermann) - 2011 (L), 2012 (Hc,Pc,L); Trichoribates trimaculatus (C.L. Koch) - 2012 (L).

Explanations: see table 3.

were more abundant in pine chips than Oribatida (Tab. 3). However, in the second year they were dominated by Oribatida and Actinedida. Yet less abundant orders identified in the study were Acaridida and Tarsonemida.

\section{Species diversity of oribatid mites}

In total, 41 species of oribatid mites were reported in the experiment (Tab. 5). The number of Oribatida species found in the litter in the years 2011-2012 was similar and equaled 29 and 27, respectively (Tab. 4). Over the 
study period, it rose from 19 to 27 species in hardwood chips and from 21 to 24 species in pine chips. Mean number of species per sample $s$ is the most accurate parameter determining species diversity of oribatid mites in large number of soil samples. Between the microplots ( $\mathrm{L}$ variant) it was high in both study years and ranged from 7.10 to 8.03 . Low value of this parameter was observed in the first year both in hardwood chips (2.23) and pine chips (3.63). Differences between the litter and the chips were significant. In the second year, $s$ increased more than twice in both substrates but the differences between means were significant only for Pc variant. In pine chips, the value of this parameter was
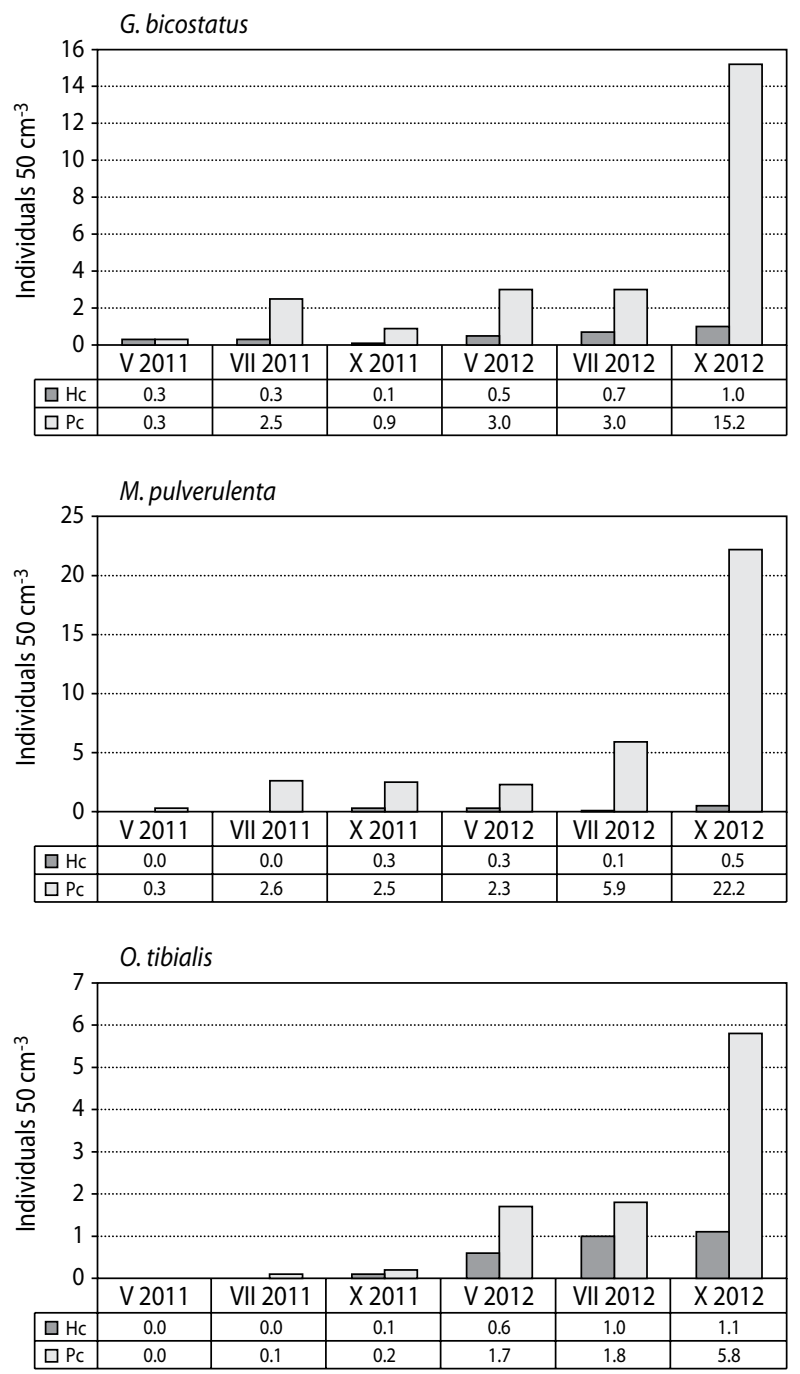

even slightly higher than in the litter for the same year. In October 2012, $s$ in Pc variant was nearly two times higher than in Hc (Fig. 2).

Shannon's diversity index $H^{\prime}$ in the investigated material ranged from 1.56 to 2.37 . Its lowest value was recorded in hardwood chips, while the highest was observed in the forest litter (Tab. 4).

\section{Analysis of occurrence of selected Oribatida species}

The most abundant oribatid mite in the investigated samples was Tectocepheus velatus that reached 0.7-21.2 individuals $50 \mathrm{~cm}^{-3}$ (Tab. 5). This species dominated in the
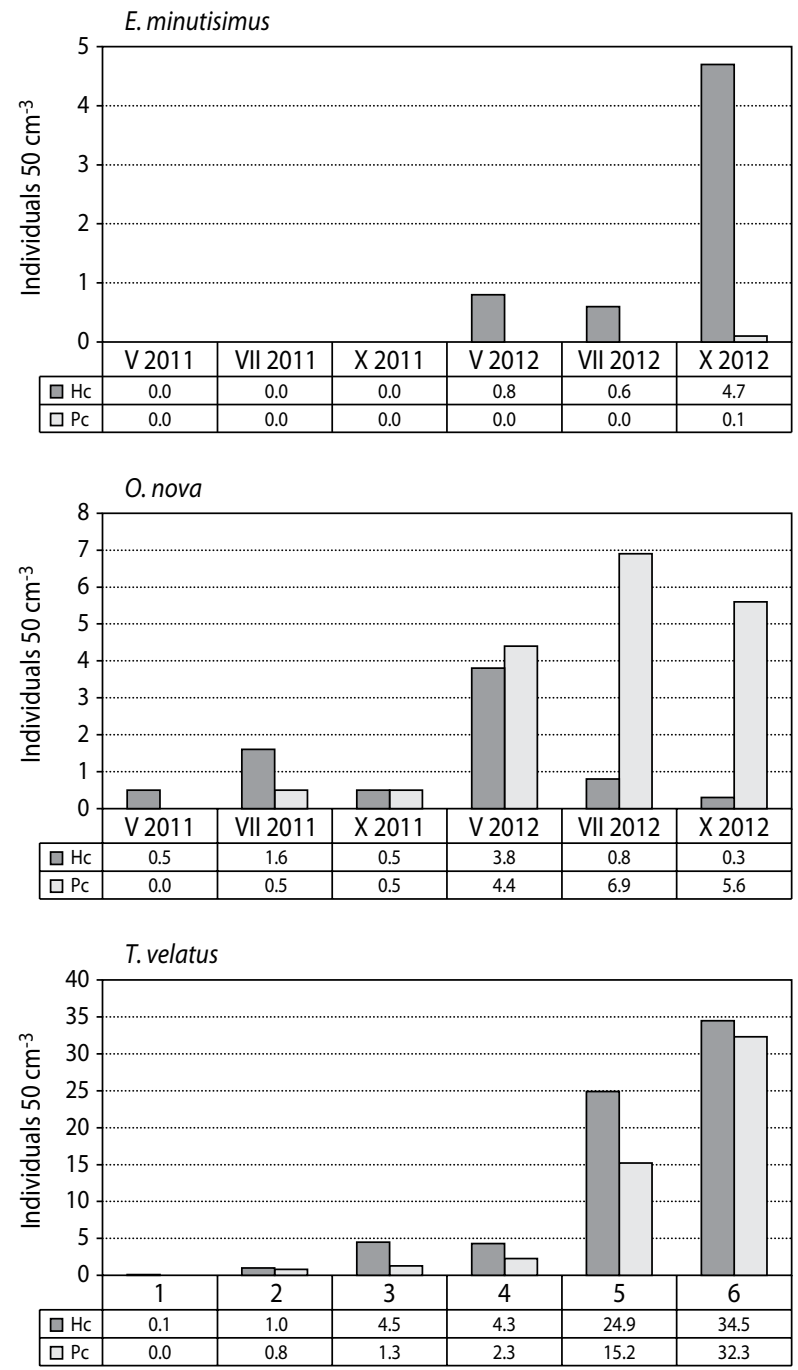

Figure 3. The dynamics of abundance of selected species of oribatid mites in the investigated experimental variants 
following years in oribatid mites communities in hardwood chips ( $D$ was 22.8 and $61.8 \%$, respectively). In pine chips and litter it dominated in 2012, with $D$ amounting to 30.3 and $32.5 \%$, respectively. No significant differences between the experimental variants were found over the next years. Significant increase in numbers was observed for each variant between the first and second year of the research. Until May 2012 T. velatus colonized both types of chips to only a small extent (Fig. 3). However, in July 2012, its abundance in hardwood chips rose by 5.8 times, and in pine chips the increase was even higher and equaled 6.6 times. Maximum abundance of Tectocepheus velatus ( 34.5 and 32.3 individuals $50 \mathrm{~cm}^{-3}$, in $\mathrm{Hc}$ and Pc variants, respectively) was observed on the last sampling date.

Gymnodamaeus bicostatus was common in the forest litter and in the years 2011 and 2012 its abundance was 7.1 and 14.1 individuals $50 \mathrm{~cm}^{-3}$ (Tab. 5). This species was less common in the chips but preferred pine chips. In this substrate, G. bicostatus was the most abundant (15.2 individuals $50 \mathrm{~cm}^{-3}$ ) on the last sampling date (Fig. 2). It was much less common on previous sampling dates.

Pine chips were abundantly colonized by Metabelba pulverulenta (10.1 individuals $50 \mathrm{~cm}^{-3}$ ) (Tab. 5), which in the first and second year of the study was the second most popular oribatid mite with $D$ amounting to 18.7 and $18.5 \%$, respectively. The species was rare in hardwood chips (0.1-0.3 individuals $\left.50 \mathrm{~cm}^{-3}\right)$, and differences between this and other variants were significant. First individuals of M. pulverulenta were detected in pine chips already in May 2011, and they were not found in hardwood chips until October 2011 (Fig. 2). Relatively high abundance of this species (5.9 individuals $50 \mathrm{~cm}^{-3}$ ) was observed in July 2012, and then it increased by almost four times from July to October.

Oppiella nova, fairly uncommon in the forest litter (0.1-0.3 individuals $50 \mathrm{~cm}^{-3}$ ) eagerly colonized the experimental chips. It was clearly more common in pine chips (5.6 individuals $50 \mathrm{~cm}^{-3}$ (Tab. 5). In Hc variant it was found as soon as in May 2011 (Fig. 2). A year later maximum abundance of $O$. nova $(3.8$ individuals $50 \mathrm{~cm}^{-3}$ ) was observed in this variant, and then it dropped to a minimum. Different pattern was detected in Pc variant, where first individuals were found in July 2011 and high abundance determined for May
2012 (4.4 individuals $50 \mathrm{~cm}^{-3}$ ) was maintained until autumn.

Oribatula tibialis, similarly as Oppiella nova, preferred pine chips. However, contrary to $O$. nova, O. tibialis was the most abundant in the forest litter in both years of the study (Tab. 5). First individuals were detected in pine chips in July 2011, and they were not found in hardwood chips until October 2011 (Fig. 2). Maximum abundance of this species (5.8 individuals $50 \mathrm{~cm}^{-3}$ ) occurred in October $2012 \mathrm{r}$. Similar abundance fluctuation pattern was observed for Chamobates schuetzi (Tab. 5). The situation was different for oribatid mites representing Suctobelba genus. These small mites eagerly colonized both types of chips already in the first year of the study, and in the latter, their numbers increased even more and were significantly higher than in the litter they migrated from.

Cluster analysis of species abundance proves that the oribatid mite in pine wood chips is more similar to the soil than the hardwood shavings (Fig. 4).

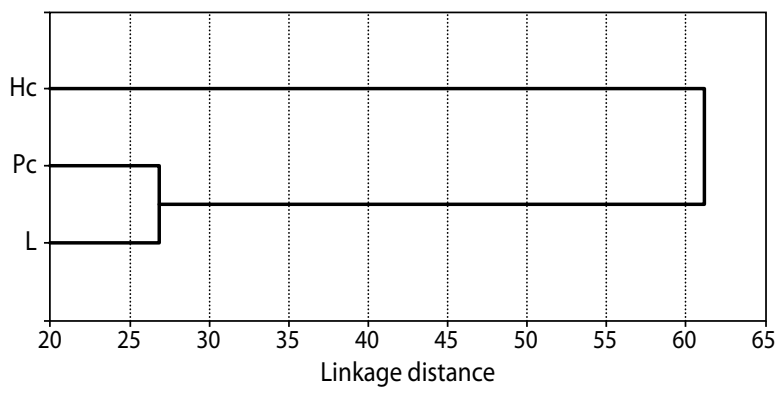

Figure 4. Dendrogram generated by the cluster analysis based the abundance of oribatid mites ( $N$ total Oribatida and $N$ of species in October 2012) on the investigated plots

\section{Discussion}

Mites, particularly oribatid mites, are considered good bioindicators of the condition of soil environment (Behan-Pelletier 1999, 2003; Gulvik 2007; Ruf and Beck 2005). These microarthropods are important components of soil environment and their functions are crucial for proper functioning of entire ecosystems, especially forest ones. They participate in soil-forming process, affect spreading of bacteria and fungi, and indirectly 
influence the occurrence of mycorrhizae (Klironomos and Kendrick 1996; Behan-Pelletier 1999; Remén et al. 2010; Schneider et al. 2005). Phytomelioration and organic fertilization of degraded soils were not enough to increase the number of beneficial microarthropods (Klimek and Kowalska 2013; Klimek and Rolbiecki 2011; Klimek et al. 2009, 2013). As mentioned before, this was probably due mainly to a lack of a protective layer of litter that is their living environment. Therefore, mulching with wood chips may be an effective solution to restore natural organic layer of soils. In this paper we analyzed the rate of wood chips colonization with mites and tried to determine whether hardwood or pine chips were more effective in revitalization of degraded forest soils.

In 2012, total number of mites in the forest litter around the microplots was two times higher than the year before. This might be due to low precipitation recorded in April and October of 2011. Literature data demonstrated that microarthropods, and particularly oribatid mites were susceptible to drought (Lindberg and Bengtsson 2005). On the microplots irrigated during drought in the first year, higher mite abundance was determined for pine wood chips. In the second year, there were no significant differences in mite abundance between the forest litter and chips. The mites belonging to different orders colonized the investigated substrates in different manner. Relatively large mites of Mesostigmata order, usually considered predators, colonized hardwood chips gradually but they were present in high numbers in pine chips from the beginning of the study. Abundance of Actinedida fluctuated within the two-year study cycle. Contrary to that, oribatid mites, which were predominant mite type, colonized both types of chips gradually. Significant increase in the proportion of juvenile oribatid mites in the second year might indicate that they originated from the eggs laid in the chips by adult forms. In a similar study involving microplots isolated from forest litter pine chips were colonized by oribatid mites at a much slower pace: in the first year their abundance was $0.2-0.8$ individuals $50 \mathrm{~cm}^{-3}$, in the second it was many times higher in May (18.3 individuals $50 \mathrm{~cm}^{-3}$ ), and then it was reduced by half (Klimek and Chachaj 2015).

A biological indicator that signals the quality of soil environment is Oribatida to Actinedida ratio (Werner and Dindal 1990; Gulvik 2007). In general, the higher the ratio the more stable the soil environment and the higher the level of its succession. Mean Oribatida to Actinedida ratio was low in hardwood chips (1.5), much higher in the forest litter surrounding the microplots (3.9), and the highest in pine chips (4.4). It was even higher in strawberry crop and equaled 12.6-16.2 (Klimek et al. 2014a). The analysis of mite communities in the investigated substrates demonstrated that pine chips were colonized faster, especially by oribatid mites, than hardwood chips. Community structure and mite abundance in pine chips was more similar to forest soil (Klimek 2000).

In the study already referenced above (Klimek and Chachaj 2015), species diversity of oribatid mites in pine chips calculated based on mean number of species per sample $s$ was only $0.2-0.4$ in the first year and 3.5-4.0 in the second year. In this study, species diversity in both years was significantly higher and the result recorded in the last season was more than three times higher. Species diversity of oribatid mites observed in October 2012 (6.7-11.7) was considered relatively high. It may be compared with strawberry crop mulched with chips, where the same indicator ranged from 2.0 to 4.2 (Klimek et al. 2014b), and in pine forest soil it was as high as around 18 (Klimek 2000). This study demonstrated that pine chips provided oribatid mites with more favorable living conditions than hardwood chips, as they were colonized at a quicker rate and by a greater number of species. This preference might be due to lower $\mathrm{pH}$ of the substrate. Low $\mathrm{pH}$ is more conducive to the development of saprotrophic fungi that are often fed on by oribatid mites (Remen et al. 2010).

The most abundant oribatid mite in the investigated substrates was Tectocepheus velatus. The species is a common soil oribatid mite present in various biotopes (Weigmann and Kratz 1981), particularly popular in Scots pine forests (Klimek 2000). It is also a pioneer species that reproduces parthenogenetically (Siepel 1994; Skubała and Gulvik 2005). Given the above, its early appearance in the investigated substrates was not unexpected. It preferred hardwood chips but the difference was not significant. Another initial and parthenogenetic species was Oppiella nova. In the beginning of the study it preferred hardwood chips but in the second year its abundance in this substrate was markedly re- 
duced. In the second year, its community appeared in pine chips and it was clearly more abundant than in the litter it migrated from.

Another species that was observed in the chips relatively early was Gymnodamaeus bicostatus. This oribatid mite is much larger than Tectocepheus velatus or Oppiella nova. Despite its high abundance in the forest litter surrounding both substrates it clearly preferred the bags with pine chips. At the beginning of the study cycle pine chips were also found to harbor Metabelba pulverulenta. Its preference to Pc variant might be due to its positive response to acidic soils (Rajski 1961). Communities of Oribatula tibialis, although abundant in the forest litter, appeared in the chips much later. This oribatid mite is a common eurytopic species (Weigmann 1991; Weigmann and Kratz 1981) that prefers forest soils (Rajski 1968). Similarly to most oribatid mites, it preferred pine chips. The only species with clear preferences for hardwood chips was Eniochthonius minutissimus. This species feeds mainly on fungi, but also feeds on forest litter (Schneider et al. 2004).

\section{Conclusions}

Mites belonging to different orders colonized hardwood and pine chips in different manner. Predatory Mesostigmata colonized hardwood chips gradually but they were present in high numbers in pine chips from the beginning of the study. Abundance of Actinedida fluctuated within the two-year study cycle. Contrary to that, oribatid mites, which were the most common mite type, colonized both types of chips gradually and preferred the pine ones. At the end of the study, the structure of mite communities and mite abundance in pine chips were more similar to forest soil than in hardwood chips.

The experiment demonstrated that pine chips provided most oribatid mites with more favorable living conditions than hardwood chips, as they were colonized at a quicker rate and by a greater number of species. The most abundant oribatid mite in both substrates was a eurytopic Tectocepheus velatus that showed no clear preferences towards either of the substrates. Majority of oribatid mites, e.g. Gymnodamaeus bicostatus, Oppiella nova, Metabelba pulverulenta, Oribatula tibialis, Chamobates schuetzi, Galumna lanceata, preferred pine chips. The only species with clear preferences for hardwood chips was Eniochthonius minutissimus.

A comparison of usefulness of hardwood and pine wood chips in revitalization of degraded soils based on bioindication approach indicated higher suitability of pine chips on habitats with Scots pine dominance especially.

\section{Acknowledgements}

The authors gratefully acknowledge considerable help provided by the Forest Nursery Białe Błota and the Forest Inspectorate in Bydgoszcz.

\section{References}

Beckmann, M. 1988. Die Entwicklung der Bodenmesofauna eines Ruderal Ökosystems und ihre Beeinflussung durch Rekultivierung: 1. Oribatiden. Pedobiologia, 31, 391-408.

Behan-Pelletier, V.M. 1999. Oribatid mite biodiversity in agroecosystems: role of bioindication. Agriculture, Ecosystems and Environment, 74, 411-423.

Behan-Pelletier, V.M. 2003. Acari and Collembola biodiversity in Canadian agricultural soils. Canadian Journal of Soil Science, 83, 279-288.

Berthet, P., Gerard, G. 1965. A statistical study of microdistribution of Oribatei (Acari) I. The distribution pattern. Oikos, 16, 214-227.

Gulvik, M.E. 2007. Mites (Acari) as indicators of soil biodiversity and land use monitoring: a review. Polish Journal of Ecology, 55 (3), 415-440.

Klimek, A. 2000. Impact of pollutants emitted by factories selected on the young-Scots-pine-forest soil mites (Acari), Oribatida in particular (in Polish with English summary). Rozprawy. ATR w Bydgoszczy, 99, 1-93.

Klimek, A., Chachaj, B. 2015. Comparison of seasonal dynamics of mite (Acari) aggregation in pine forest litter and pine chips. Infrastructure and Ecology of Rural Areas, 2 (2), 405-417.

Klimek, A., Chachaj, B., Sas-Paszt, L., Frąc, M., Przybył, M., Sumorok, B., Treder, W. 2014a. Soil mites (Acari) in the cultivation of strawberries 
mulched with wood chips (in Polish with English summary). Infrastructure and Ecology of Rural Areas, 2 (3), 849-863.

Klimek, A., Chachaj, B., Sas-Paszt, L., Treder, W., Tryngiel-Gać, A., Błachowicz, K. 2014b. Seasonal dynamics of the occurrence of soil mites (Acari) on strawberry plantations mulched with wood chips and in a nearby patch of grass (in Polish with English summary). Infrastructure and Ecology of Rural Areas, 2 (3), 865-879.

Klimek, A., Kowalska, A. 2013. Forest comparison of soil mites (Acari) on post-arable land and land in the initial stage of forest succession (in Polish with English summary). Infrastructure and Ecology of Rural Areas, 3 (1), 47-57.

Klimek, A., Rolbiecki, S. 2011. Growth of Scots pine (Pinus sylvestris L.) and occurrence of soil mites (Acari) on the reclaimed post-military area at forest district Żołędowo (in Polish with English summary). Infrastructure and Ecology of Rural Areas, 1, 249-262.

Klimek, A., Rolbiecki, S., Rolbiecki, R. 2013. Effect of irrigation and organic fertilization on oribatid mites (Acari, Oribatida) in forest nursery. Scientific Research and Essays, 8 (5), 227-237.

Klimek, A., Rolbiecki, S., Rolbiecki, R., Malczyk, P. 2009. Impact of chosen bare root nursery practices on white birch seedling quality and soil mites (Acari). Polish Journal of Environmental Studies, 18 (6), 1013-1020.

Klironomos, J.N., Kendrick, W.B. 1996. Palatability of microfungi to soil arthropods in relation to the functioning of arbuscular mycorrhizae. Biology and Fertility of Soils, 21, 43-52.

Lehmitz, R., Russell, D., Hohberg, K., Christian, A., Xylander, W.E.R. 2012. Active dispersal of oribatid mites into young soils. Applied Soil Ecology, 55, $10-19$.

Lindberg, N., Bengtsson, J. 2005. Population responses of oribatid mites and collembolans after drought. Applied Soil Ecology, 28, 163-174.

Rajski, A. 1968. Autecological-zoogeographical analysis of moss mites (Acari, Oribatei) on the basis of fauna in the Poznań environs. Part II. Fragmenta Faunistica, 12, 277-405.

Rajski, A. 1961. Faunistic-ecological investigations on moss mites (Acari, Oribatei) in several plant asso- ciations. I. Ekologia (in Polish). Prace Komisji Biologicznej, 25, 123-283.

Remén, C., Fransson, P., Persson, T. 2010. Population responses of oribatids and enchytraeids to ectomycorrhizal and saprotrophic fungi in plantesoil microcosms. Soil Biology and Biochemistry, 42, 978-985.

Ruf, A., Beck, L. 2005. The use of predatory soil mites in ecological soil classification and assessment concepts, with perspectives for oribatid mites. Ecotoxicology and Environmental Safety, 62, 290-299.

Sadowski, J., Moskalik, T., Zastocki, D., Wrona, T. 2012. Selected Economic and Nature-related Aspects of Logging Residues Management and Utilization. Studia i Materiaty CEPL w Rogowie, 14, 32 (3), 246-253.

Schneider, K., Renker, C., Maraun, M. 2005. Oribatid mite (Acari, Oribatida) feeding on ectomycorrhizal fungi. Mycorrhiza, 16, 67-72.

Schneider, K., Migge, S., Norton, R.A., Scheu, S., Langel, R., Reineking, A., Marauna, M. 2004. Trophic niche differentiation in oribatid mites (Oribatida, Acari): evidence from stable isotope $\operatorname{ratios}\left({ }^{15} \mathrm{~N} /{ }^{14} \mathrm{~N}\right)$. Soil Biology and Biochemistry, 36, 1769-1774.

Siepel, H. 1994. Life - history tactics of soil microarthropods. Biology and Fertility of Soils, 18, 263-278.

Skubała, P., Gulvik, M. 2005. Pioneer oribatid mite communities (Acari: Oribatida) in natural (glacier foreland) and anthropogenic (post-industrial dumps) habitats. Polish Journal of Ecology, 53, 105-111.

Treder, W., Klamkowski, K., Krzewińska, D., TryngielGać, A. 2009. The latest trends in irrigation technology - research related to irrigation of fruit crops conducted at the research institute of pomology and floriculture in Skierniewice (in Polish with English summary). Infrastructure and Ecology of Rural Areas, 6, 95-107.

Treder, W., Klamkowski, K., Mika, A., Wójcik, P. 2004. Response of young apple trees to different orchard floor management system. Journal of Fruit and Ornamental Plant Research, 12, Special ed., 109-119.

Wanner, M., Dunger, W. 2002. Primary immigration and succession of soil organisms on reclaimed 
opencast coal mining areas in eastern Germany. European Journal of Soil Biology, 38, 137-143.

Weigmann, G. 1991. Oribatid communities in transects from bogs to forests in Berlin indicating the biotope qualities. In: Proceedings of 8th International Congress on Acarology. Modern Acarology 1 (eds. F. Dusbanek, V. Bukva), České Budějovice, 359-364. Weigmann, G., Kratz, W. 1981. Die deutschen Hornmilbenarten und ihre ökologische Charakteristik. Zoologische Beiträge, 27, 459-489.

Werner, M.R., Dindal, D.L. 1990. Effects of conversion to organic practices agricultural on soil biota. American Journal of Alternative Agriculture, 5, 24-32. 